\section{Is there still room for novelty, in histochemical papers?}

\author{
C. Pellicciari \\ Department of Biology and \\ Biotechnology, University of Pavia, Italy
}

\section{Abstract}

Histochemistry continues to be widely applied in biomedical research, being nowadays mostly addressed to detect and locate single molecules or molecular complexes inside cells and tissues, and to relate structural organization and function at the high resolution of the more advanced microscopical techniques. In the attempt to see whether histochemical novelties may be found in the recent literature, the articles published in the European Journal of Histochemistry in the period 2014-2016 have been reviewed. In the majority of the published papers, standardized methods have been preferred by scientists to make their results reliably comparable with the data in the literature, but several papers (approximately one fourth of the published articles) described novel histochemical methods and procedures. It is worth noting that there is a growing interest for minimally-invasive in vivo techniques (magnetic resonance imaging, autofluorescence spectroscopy), which may parallel conventional histochemical analyses to acquire evidence not only on the morphological features of living organs and tissues, but also on their functional, biophysical and molecular characteristics. Thanks to this unceasing methodological refinement, histochemistry will continue to provide innovative applications in the biomedical field.

\section{Introduction}

The impact of Histochemistry on biological and medical research is always high, ${ }^{1-3}$ with widespread application in a large variety of topics. During the last three years, more than 65,000 articles have been published in qualified journals (according to the Web of Science and Scopus databases), and it would be interesting to know how histochemistry has been used, especially which techniques have been employed in these investigations: this would also help to answer the question "was there histochemical originality or novelty, or just instrumental application of accepted protocols?". A survey of the whole histochemical production would have been a too difficult task; therefore, a review has been made of only the 126 articles published in the European Journal of Histochemistry from January 2014 to present. This journal traditionally accepts manuscript on functional cell and tissue biology in animals and plants, with attention to the processes of cell differentiation, development and senescence, and to the cellular basis of diseases: this should make the article sample sufficiently representative of the possible histochemical applications, though obviously limited by the small number of items considered.

For sake of simplicity, the papers have been divided into six categories, based on their main subject: Tumor biology \& markers (14\% of the published articles), Non-Tumors diseases (17\%), Experimental medicine \& Animal models (10\%), Stem cells \& Development (14\%), Tissue Biology in Human and Animals (20\%), Methods \& Techniques (25\%).

\section{Tumor biology \& markers, Non-Tumors diseases , Experimental Medicine \& Animal Models}

In most of the published papers on Tumor biology \& markers, ${ }^{4-21}$ the expression of specific protein has been investigated (in hepatocellular carcinoma, ${ }^{4-6}$ uterine lesions, ${ }^{7,8}$ colorectal carcinoma, ${ }^{9,10}$ and other neoplasms ${ }^{11,15,21}$ ). The aim was either to originally define new diagnostic/prognostic markers, ${ }^{4,6,8,10-12}$ or to identify proteins involved in tumor onset ${ }^{7}$ or progression, ${ }^{5,21}$ or to evaluate the effect of therapy. ${ }^{9}$ The mechanisms of carcinogenesis have also been studied, ${ }^{13-20}$ and it is worth noting that some new proteins have been identified as potential therapeutic targets for cancer treatment $^{14,16}$ and tailored therapy. ${ }^{20,21}$ In most of these investigations, well-established immunohistochemical methods have been used (often in parallel with in situ hybridization, RT-PCR, Western blot assays or microarray analyses) to detect and locate single molecular species inside tissues and cells or in the extracellular matrix.

A similar situation may be found in the articles on Non-Tumors diseases. ${ }^{22-42}$ Here again, multiple immunohistochemical assays have mostly been used to identify pathogenetic factors or to relate the changes in protein expression with tissue remodeling,,$^{22,29-33}$ or the progression of the disease..$^{23-28,34,35}$ Interestingly, cartilage, bone and dentin in different pathologies were especially investigated, ${ }^{36-41}$ which demonstrates the unique role of histochemistry in studying these tissues under normal or pathological conditions. ${ }^{42}$

The effect of experimental treatments or disease on the fibrous joint tissue $\mathrm{e}^{43,44}$ and car-
Correspondence: Carlo Pellicciari,

Dipartimento di Biologia e Biotecnologie "Lazzaro Spallanzani",

Università degli Studi di Pavia, Via A. Ferrata 9, 27100 Pavia, Italy.

E-mail: carlo.pellicciari@unipv.it

Key words: Basic and applied histochemistry; biomedical research; histochemical methods

Received for publication: 12 December 2016. Accepted for publication: 15 December 2016.

This work is licensed under a Creative Commons Attribution-NonCommercial 4.0 International License (CC BY-NC 4.0).

(C) Copyright C. Pellicciari, 2016

Licensee PAGEPress, Italy

European Journal of Histochemistry 2016; 60:2758 doi:10.4081/ejh.2016.2758

tilage $^{45,46}$ were also investigated in papers falling into the category Experimental Medicine \& Animal Models. ${ }^{43-54}$ In this article group, conventional histochemical techniques, histological examination and morphometry at light and electron microscopy were often used together with immunohistochemistry, to describe the structural organization of brain ${ }^{46}$ or the skeletal muscle ${ }^{47}$ in mice strains, and to investigate in rats the effects of a maternal dietary load of alpha-tocopherol on the synapse density and glial synaptic coverage in the hippocampus of adult offspring. ${ }^{48}$ Enzyme histochemistry and immunolabeling were simultaneously applied to describe the structural and functional organization of fatty livers submitted to a preservation procedure especially suitable for organ transplantation. ${ }^{49}$

Cultured cell systems have also been used to analyze the effect of ozone at low concentration on cytoskeletal organization, mitochondrial activity and nuclear transcription, ${ }^{52}$ or to elucidate the molecular pathway responsible for the increased collagen synthesis by fibroblasts in vitro after exposure to the natural flavonoid, apigenin..$^{53}$ In these articles, the use of multiple molecular and histochemical techniques at light and electron microscopy was effective to detect changes in gene expression and in the structural organization and function of subcellular organelles.

\section{Stem cells \& Development, Tissue Biology in Human and Animals}

In the papers on Stem cells \& Development ${ }^{55-72}$ the expression of specific proteins was investi- 
gated during fetal development, ${ }^{55}$ with particular reference to skin, ${ }^{56}$ lung ${ }^{57,58}$ kidney, ${ }^{59}$ pituitary and adrenal gland, ${ }^{60,61}$ developing cartilage and bone, ${ }^{62-65}$ and cochlea. ${ }^{66,67}$ The presence of progenitor stem cells has been detected in the kidney, ${ }^{68}$ cerebral cortex ${ }^{69}$ and cerebellum ${ }^{70}$ during human embryogenesis. Viable chondrogenic stem cells have been detected in the knee joint loose body, ${ }^{71}$ and the ultrastructural features of mesenchymal stem cells after in vitro expansion have been reviewed. ${ }^{72}$ Histochemistry proved to be especially suitable also for the essentially descriptive articles on Tissue Biology in Human \& Animals. ${ }^{73-98}$ Here, several proteins and protein receptors have been studied in different organs and tissues from mammals (rodents, ${ }^{73-82}$ bat, ${ }^{83} \mathrm{dog},{ }^{84}$ primates and human ${ }^{85-88}$ ), as well as from lower vertebrate $^{89-94}$ and invertebrates. ${ }^{95}$ Few papers described the peculiar behavior of nuclear proteins involved in RNA transcription and maturation $^{96}$ or in apoptotic cell death..$^{97-98}$

\section{Methods \& Techniques}

In the great majority of the papers of all the above mentioned categories, techniques have been used to locate single proteins or nuclei acid sequences in situ (single or multiple immunohistochemistry, in situ hybridization). In these investigations, the scientists obviously preferred to use standardized methods to make their results reliably comparable with the data in the literature. As a consequence, originality resides in the investigated subjects, whereas histochemical novelty may hardly be found and, when seldom present, it is limited to the appropriate protocol adjustment to cope with special sample characteristics.

On the contrary, the papers in the section Methods \& Techniques ${ }^{99-129}$ are histochemically novel either in the proposed procedure and in its application to unusual model systems. The key role of the fixation/embedding procedures for appropriate specimen preparation was demonstrated in some studies, ${ }^{99-104}$ and particular attention was paid to technical improvements in antigen preservation and retrieval for immunohistochemical applications, ${ }^{105-110}$ and in multiple histochemical staining. ${ }^{111-113}$ Imaging techniques were the subject of some articles. ${ }^{114-116}$ Raman microspectroscopy was used to investigate stenotic aortic valve leaflets to get information on the composition and distribution of accumulated lipids, in the attempt to correlate their presence with mineralization as a precocious diagnostic marker. ${ }^{114}$ Magnetic resonance imaging (MRI) was used to perform a longitudinal study in vivo on the spine changes occurring in an experimental rat model of ankylosing spondylitis, and the obtained results were validated at the end of the experiments by micro-computerized tomography and histological examination: this non-invasive approach may potentially be applied to follow the progress of this disease and plan therapeutic interventions in humans. ${ }^{115}$ Advanced MRI techniques, such as MRI microscopy, Magnetic Resonance Spectroscopy, functional MRI, and Diffusion Tensor Imaging may be envisaged as suitable minimally-invasive techniques to investigate in vivo not only the morphological features of living organs and tissues, but also their functional, biophysical and molecular characteristics. ${ }^{116}$ Among the non-invasive techniques, autofluorescence imaging promise to be particularly suitable and informative for diagnostic applications. ${ }^{117-120}$ Applications of electron microscopy analyses were used for tridimensional reconstruction of apoptotic nuclei ${ }^{121}$ and for detecting metal contaminants. ${ }^{122-124}$ Diaminobenzidine photo-oxidation by fluorescent probes was used for detecting at electron microscopy calcium ions, ${ }^{125}$ for visualizing endocytotic pathways ${ }^{126}$ and for tracking nanoparticles inside the cells. ${ }^{127,128}$ These last articles demonstrate that new varied applications in nanomedicine may be envisaged for ultrastructural histochemistry. ${ }^{129}$

\section{Concluding remarks}

This short survey plainly confirms that histochemical research is presently addressed to identify single molecules, ${ }^{130}$ and to dynamically describe their intracellular location and movements; in fact, nowadays papers are rarely found where conventional histochemical techniques are used to label or quantify large macromolecular categories, such as whole proteins or nucleic acids in single cells or tissues.

Even in the small sample considered, approximately one fourth of the articles describe new or improved histochemical methods or the adaptation to electron microscopy of techniques originally designed for light microscopy; this is consistent with the recent reports on the papers published in another classical Journal of histochemistry. ${ }^{1,131}$ Thanks to this unceasing methodological refinement, histochemistry will continue to provide novel applications in the biomedical field.

In the last decade, new technologies have been developed which made it possible to break or bypass the classical Abbe's diffraction limit. ${ }^{131,132}$ They are collectively known as superresolution microscopy, and pushed the optical resolution down to the molecular level. ${ }^{133}$ This has opened unexpected opportunities for the application of histochemistry at the nanoscale: using highly specific fluorescent labeling by immunocytochemistry, or in situ hybridization, or fluorescent protein probes, the spatial distribution and dynamics of molecules (genome sequences, RNAs or proteins) can be investigated in every subcellular organelle or structure, in living or fixed samples ${ }^{134}$ with a resolution comparable to electron microscopy and the unique flexibility of multicolor fluorescence microscopy.

So we may surely answer the title question: "yes: there still room for novelty in histochemical papers!".

\section{References}

1. Taatjes DJ, Roth J. The Histochemistry and Cell Biology omnium-gatherum: the year 2015 in review. Histochem Cell Biol 2016;145:239-74.

2. Pellicciari C. Impact of Histochemistry on biomedical research: looking through the articles published in a long-established histochemical journal. Eur J Histochem 2014;58:2474.

3. Pellicciari C. Histochemistry in biology and medicine: a message from the citing journals. Eur J Histochem 2015;59:2610.

4. Guerriero E, Accardo M, Capone F, Colonna G, Castello G, Costantini S. Assessment of the Selenoprotein M (SELM) over-expression on human hepatocellular carcinoma tissues by immunohistochemistry. Eur J Histochem 2014;58:2433.

5. Theunissen W, Fanni D, Nemolato S, Di Felice E, Cabras T, Gerosa C, et al. Thymosin beta 4 and thymosin beta 10 expression in hepatocellular carcinoma. Eur J Histochem 2014;58:2242.

6. Guerriero E, Capone F, Accardo M, Sorice A, Costantini M, Colonna G, et al. GPX4 and GPX7 over-expression in human hepatocellular carcinoma tissues. Eur J Histochem 2015;59:2540.

7. Lindstrom AK, Hellberg D. Immunohistochemical LRIG3 expression in cervical intraepithelial neoplasia and invasive squamous cell cervical cancer: association with expression of tumor markers, hormones, high-risk HPV-infection, smoking and patient outcome. Eur J Histochem 2014;58:2227.

8. Clark ATR, Guimaraes da Costa VML, Bandeira Costa L, Bezerra Cavalcanti CL, de Melo Rêgo MJB, Beltrão EIC. Differential expression patterns of $\mathrm{N}$ acetylglucosaminyl transferases and polylactosamines in uterine lesions. Eur $\mathrm{J}$ Histochem 2014;58:2334.

9. Buldak R J, Skonieczna M, Buldak L, Matysiak N, Mielańczyk $\quad €$, Wyrobiecet G, et al. Changes in subcellular localiza- 
tion of visfatin in human colorectal HCT116 carcinoma cell line after cytochalasin B treatment. Eur J Histochem 2014;58:2408.

10. Demirovic A, Cesarec S, Marusic Z, Tomas D, Milosevic M, Hudolin T, et al. TGF-betal expression in chromophobe renal cell carcinoma and renal oncocytoma. Eur J Histochem 2014;58:2265.

11. Araujo DGB, Nakao L, Gozzo P, Souza CDA, Balderrama V, Gugelmin ES, et al. Expression level of quiescin sulfhydryl oxidase 1 (QSOX1) in neuroblastomas. Eur J Histochem 2014;58:2228.

12. Chene G, Radosevic-Robin N, Tardieu AS, Cayre A, Raoelfils I, Dechelotte P, et al. Morphological and immunohistochemical study of ovarian and tubal dysplasia associated with tamoxifen. Eur J Histochem 2014;58:2251.

13. Zhang J, Luo J, Ni J, Tang L, Zhang HP, Zhang L, et al. MMP-7 is upregulated by COX-2 and promotes proliferation and invasion of lung adenocarcinoma cells. Eur J Histochem 2014;58:2262.

14. Ou J M, Yu ZY, Qiu MK, Dai YX, Dong Q, Shen J, et al. Knockdown of VEGFR2 inhibits proliferation and induces apoptosis in hemangioma-derived endothelial cells. Eur J Histochem 2014;58:2263.

15. Fantinato E, Milani L, Sironi G. Sox9 expression in canine epithelial skin tumors. Eur J Histochem 2015;59:2514.

16. Costa YF, Tjioe KC, Nonogaki S, Soares FA, Lauris JR, Oliveira DT. Are podoplanin and ezrin involved in the invasion process of the ameloblastomas? Eur J Histochem 2015;59:2451.

17. Porzionato A, Rucinski M, Macchi V, Sarasin G, Malendowicz LK, De Caro R. ECRG4 expression in normal rat tissues: expression study and literature review. Eur J Histochem 2015;59:2458.

18. Waisberg J, Theodoro TR, Matos LL, Orlandi FB, Serrano RL, Saba GT, et al. Immunohistochemical expression of heparanase isoforms and syndecan-1 proteins in colorectal adenomas. Eur $\mathrm{J}$ Histochem 2016;60:2590.

19. Caocci G, Greco M, Fanni D, Senes G, Littera R, Lai S, et al. HLA-G expression and role in advanced-stage classical Hodgkin lymphoma. Eur J Histochem 2016;60:2606.

20. Al-dhohorah T, Mashrah M, Yao Z, Huang J. Aberrant DKK3 expression in the oral leukoplakia and oral submucous fibrosis: a comparative immunohistochemical study. Eur J Histochem 2016;60:2629.

21. Fanni D, Manchia M, Lai F, Gerosa C, Ambu R, Faa G. Immunohistochemical markers of CYP3A4 and CYP3A7: a new tool towards personalized pharmacother- apy of hepatocellular carcinoma. Eur $\mathrm{J}$ Histochem 2016;60:2614.

22. Sun Y, Zhu L, Huang X, Zhou C, Zhang X. Immunohistochemical localization of nerve fibers in the pseudocapsule of fibroids. Eur J Histochem 2014;58:2249.

23. Hu SS, Mei L, Chen JY, Huang ZW, Wu H. Expression of immediate-early genes in the inferior colliculus and auditory cortex in salicylate-induced tinnitus in rat. Eur J Histochem 2014;58:2294

24. Karavana VN, Gakiopoulou H, Lianos EA. Expression of Ser729 phosphorylated PKC epsilon in experimental crescentic glomerulonephritis: an immunohistochemical study. Eur J Histochem 2014;58:2308.

25. Demurtas P, Corrias M, Zucca I, Maxia C, Piras F, Sirigu P, et al. Angiotensin II: immunohistochemical study in Sardinian pterygium. Eur J Histochem 2014;58:2426.

26. Arcucci A, Ruocco MR, Albano F, Granato G, Romano V, Corso G, et al. Analysis of extracellular superoxide dismutase and Akt in ascending aortic aneurysm with tricuspid or bicuspid aortic valve. Eur J Histochem 2014;58:2383.

27. Janiuk I, Kasacka I. Quantitative evaluation of CART-containing cells in urinary bladder of rats with renovascular hypertension. Eur J Histochem 2015;59:2446

28. Di Vito A, Scali E, Ferraro G, Mignogna C, Presta I, Camastra C, et al. Elastofibroma dorsi: a histochemical and immunohistochemical study. Eur J Histochem 2015;59: 2459.

29. Goteri G, Altobelli E, Tossetta G, Zizzi A, Avellini C, Licini C, et al. High temperature requirement $\mathrm{Al}$, transforming growth factor beta1, phosphoSmad2 and Ki67 in eutopic and ectopic endometrium of women with endometriosis. Eur J Histochem 2015;59:2570.

30. Tossetta G, Avellini C, Licini C, Giannubilo SR, Castellucci M, Marzioni D. High temperature requirement $\mathrm{Al}$ and fibronectin: two possible players in placental tissue remodelling. Eur $\mathrm{J}$ Histochem 2016;60:2724.

31. Knabl J, Vattai A, Hüttenbrenner R, Hutter S, Karsten M, Jeschke U. RXR $\alpha$ is upregulated in first trimester endometrial glands of spontaneous abortions unlike LXR and PPARY. Eur J Histochem 2016;60:2665.

32. Vetuschi A, D'Alfonso A, Sferra R, Zanelli D, Pompili S, Patacchiola F, et al. Changes in muscularis propria of anterior vaginal wall in women with pelvic organ prolapse. Eur J Histochem 2016;60:2604.

33. Cutroneo G, Vermiglio G, Centofanti A, Rizzo G, Runci M, Favaloro A, et al.
Morphofunctional compensation of masseter muscles in unilateral posterior crossbite patients. Eur J Histochem 2016;60:2605.

34. Renna LV, Cardani R, Botta A, Rossi G, Fossati B, Costa E, et al. Premature senescence in primary muscle cultures of myotonic dystrophy type 2 is not associat ed with p16 induction. Eur J Histochem 2014;58:2444.

35. Severi C, Sferra R, Scirocco A, Vetuschi A, Pallotta N, Pronio A, et al. Contribution of intestinal smooth muscle to Crohn's disease fibrogenesis. Eur J Histochem 2014;58:2457.

36. Orsini G, Majorana A, Mazzoni A, Putignano A, Falconi M, Polimeni A, et al. Immunocytochemical detection of dentin matrix proteins in primary teeth from patients with dentinogenesis imperfecta associated with osteogenesis imperfecta. Eur J Histochem 2014;58:2405.

37. Loreto C, Galanti C, Musumeci G, Rusu MC, Leonardi R. Immunohistochemical analysis of matrix metalloproteinase-13 in human caries dentin. Eur J Histochem 2014;58:2318.

38. Loreto C, Psaila A, Musumeci G, Castorina S, Leonardi R. Apoptosis activation in human carious dentin. An immunohistochemical study. Eur J Histochem 2015;59:2513.

39. Leonardi R, Perrotta RE, Loreto C, Musumeci G, Crimi S, Dos Santos JN, et al. Toll-like receptor 4 expression in the epithelium of inflammatory periapical lesions. An immunohistochemical study. Eur J Histochem 2015;59:2547.

40. Cobo T, Obaya A, Cal S, Solares L, Cabo R, Vega JA, et al. Immunohistochemical localization of periostin in human gingiva. Eur J Histochem 2015;59:2548.

41. Di Nisio C, Zizzari VL, S Zara, Falconi M, Teti G, Tetè G, et al. RANK/RANKL/OPG signaling pathways in necrotic jaw bone from bisphosphonate-treated subjects. Eur J Histochem 2015;59:2455.

42. Musumeci G, Castrogiovanni P, Mazzone V, Szychlinska MA, Castorina S, Loreto C. Histochemistry as a unique approach for investigating normal and osteoarthritic cartilage. Eur J Histochem 2014;58:2371.

43. Shinohara Y, Okamoto K, Goh Y, Kiga N, Tojyo I, Fujita S. Inhibition of fibrous adhesion formation in the temporomandibular joint of tenascin- $\mathrm{C}$ knockout mice. Eur J Histochem 2014;58:2337.

44. Okamoto K, Kiga N, Shinohara Y, Tojyo I, Fujita S. Effect of interleukin-1beta and dehydroepiandrosterone on the expression of lumican and fibromodulin in fibroblast-like synovial cells of the human temporomandibular joint. Eur J 
Histochem 2015;59:2440.

45. Di Rosa M, Szychlinska M A, Tibullo D, Malaguarnera L, Musumeci G. Expression of CHI3L1 and CHIT1 in osteoarthritic rat cartilage model. A morphological study. Eur J Histochem 2014;58:2423

46. Xu HG, Zhang W, Zheng Q, Yu YF, Deng $\mathrm{LF}$, Wang $\mathrm{H}$, et al. Investigating conversion of endplate chondrocytes induced by intermittent cyclic mechanical unconfined compression in three-dimensional cultures. Eur J Histochem 2014;58:2415.

47. Insolia V, Piccolini VM. Brain morphological defects in prolidase deficient mice: first report. Eur J Histochem 2014;58:2417.

48. Kocsis T, Baan J, Muller G, L Mendler, Dux L, Keller-Pintér A. Skeletal muscle cellularity and glycogen distribution in the hypermuscular Compact mice. Eur J Histochem 2014;58:2353.

49. Salucci S, Ambrogini P, Lattanzi D, Betti M, Gobbi P, Galati C, et al. Maternal dietary loads of alpha-tocopherol increase synapse density and glial synaptic coverage in the hippocampus of adult offspring. Eur J Histochem 2014;58:2355.

50. Tarantola E, Bertone V, Milanesi G, Gruppi C, Ferrigno A, Vairetti M, et al. Dipeptidylpeptidase-IV activity and expression reveal decreased damage to the intrahepatic biliary tree in fatty livers submitted to subnormothermic machineperfusion respect to conventional cold storage. Eur J Histochem 2014;58:2414.

51. Suchankova J, Legartova S, Sehnalova P, S Kozubek, Valente S, Labella D, et al. PRMT1 arginine methyltransferase accumulates in cytoplasmic bodies that respond to selective inhibition and DNA damage. Eur J Histochem 2014;58:2389.

52. Ferreira MJr, Batista SA, Vidigal PVT, Cordeiro AAC, Oliveira FMS, Prata LO, et al. Infection with CagA-positive Helicobacter pylori strain containing three EPIYA C phosphorylation sites is associated with more severe gastric lesions in experimentally infected Mongolian gerbils (Meriones unguiculatus) . Eur J Histochem 2015;59:2489.

53. Costanzo M, Cisterna B, Vella A, Cestari T, Covi V, Tabaracci G, et al. Low ozone concentrations stimulate cytoskeletal organization, mitochondrial activity and nuclear transcription. Eur J Histochem 2015;59:2515.

54. Zhang Y, Wang J, Cheng X, Yi B, Zhang X, Li Q. Apigenin induces dermal collagen synthesis via smad2/3 signaling pathway. Eur J Histochem 2015;59:2467.

55. Ambu R, Vinci L, Gerosa C, Fanni D, Obinu E, Faa A, et al. WT1 expression in the human fetus during development. Eur
J Histochem 2015;59:2499.

56. Ferretti V, Segal-Eiras Á, Barbeito CG, Croce MV. Muc5ac mucin expression during rat skin development. Eur $\mathrm{J}$ Histochem 2015;59:2462.

57. Kato T, Oka K, Nakamura T, Ito A. Decreased expression of Met during differentiation in rat lung. Eur J Histochem 2016;60:2575.

58. Cau F, Pisu E, Gerosa C, Senes G, Ronchi $\mathrm{F}$, Botta $\mathrm{C}$, et al. Interindividual variability in the expression of surfactant protein $\mathrm{A}$ and $B$ in the human lung during development. Eur J Histochem 2016;60:2678.

59. Song JH, Lee MY, Kim YJ, Park SR, Kim J, Ryu SY, et al. Developmental immunolocalization of the Klotho protein in mouse kidney epithelial cells. Eur J Histochem 2014;58:2256.

60. Sandhu MA, Saeed AA, Khilji MS, Pasha RH, Mukhtar N, Anjum MS, et al. Ontogenic development of corticotrophs in fetal buffalo (Bubalus bubalis) pituitary gland. Eur J Histochem 2014;58: 2292.

61. Karaca T, Hulya Uz Y, Karabacak R, Karaboga I, Demirtas S, Cagatay Cicek A. Effects of hyperthyroidism on expression of vascular endothelial growth factor (VEGF) and apoptosis in fetal adrenal glands. Eur J Histochem 2015;59:2560.

62. Tsukamoto I, Akagi M, Inoue $\mathrm{S}$, Yamagishi K, Mori S, Asada S. Expressions of local renin-angiotensin system components in chondrocytes. Eur J Histochem 2014;58:2387.

63. Fujikawa K, Yokohama-Tamaki T, Morita T, Baba 0, Qin C, Shibata S. An in situ hybridization study of perlecan, DMP1, and MEPE in developing condylar cartilage of the fetal mouse mandible and limb bud cartilage. Eur J Histochem 2015;59: 2553.

64. Carvalho de Moraes LO, Tedesco RC, Arraez-Aybar LA, Klein 0, Mérida-Velasco JR, Alonso LG. Development of synovial membrane in the temporomandibular joint of the human fetus. Eur J Histochem 2015;59:2569.

65. Zhang H, Liu P, Wang S, Liu C, Jani P, Lu $\mathrm{Y}$, et al. Transgenic expression of dentin phosphoprotein inhibits skeletal development. Eur J Histochem 2016;60:2587.

66. Liu WJ, Yang J. Preferentially regulated expression of connexin 43 in the developing spiral ganglion neurons and afferent terminals in post-natal rat cochlea. Eur J Histochem 2015;59:2464.

67. Liu WJ, Yang J. Developmental expression of inositol 1, 4, 5-trisphosphate receptor in the post-natal rat cochlea. Eur J Histochem 2015;59:2486.

68. Hansson J, Ericsson AE, Axelson H, Johansson ME. Species diversity regard- ing the presence of proximal tubular progenitor cells of the kidney. Eur $\mathrm{J}$ Histochem 2016;60:2567.

69. Vinci L, Ravarino A, Fanos V, Naccarato AG, Senes G, Gerosa C, et al. Immunohistochemical markers of neural progenitor cells in the early embryonic human cerebral cortex. Eur J Histochem 2016;60:2563.

70. Pibiri V, Ravarino A, Gerosa C, Pintus MC, Fanos V, Faa G. Stem/progenitor cells in the developing human cerebellum: an immunohistochemical study. Eur J Histochem 2016;60:2686.

71. Melrose J. The knee joint loose body as a source of viable autologous human chondrocytes. Eur J Histochem 2016;60:2645.

72. Miko M, Danišovič L, Majidi A, Varga I. Ultrastructural analysis of different human mesenchymal stem cells after in vitro expansion: a technical review. Eur J Histochem 2015;59:2528.

73. Bao L, Li Q, Liu Y, Li B, Sheng X, Han Y, et al. Immunolocalization of NGF and its receptors in ovarian surface epithelium of the wild ground squirrel during the breeding and nonbreeding seasons. Eur J Histochem 2014;58:2363.

74. Zhang H, Wang Y, Zhang J, Wang L, Li Q, Sheng $X$, et al. Testicular expression of NGF, TrkA and p75 during seasonal spermatogenesis of the wild ground squirrel (Citellus dauricus Brandt). Eur J Histochem 2015;59:2522.

75. Li Q, Zhang F, Zhang S, Sheng X, Han X, Weng $Q$, et al. Seasonal expression of androgen receptor, aromatase, and estrogen receptor alpha and beta in the testis of the wild ground squirrel (Citellus dauricus Brandt). Eur J Histochem 2015;59: 2456.

76. Zhang F, Wang J, Jiao Y, Zhang L, Zhang $\mathrm{H}$, Sheng $\mathrm{X}$, et al. Seasonal changes of androgen receptor, estrogen receptors and aromatase expression in the medial preoptic area of the wild male ground squirrels (Citellus dauricus Brandt). Eur J Histochem 2016;60:2621.

77. Golic I, Velickovic K, Markelic M, Stancic A, Jankovic A, Vucetic M, et al. Calciuminduced alteration of mitochondrial morphology and mitochondrial-endoplasmic reticulum contacts in rat brown adipocytes. Eur J Histochem 2014;58: 2377.

78. Romero-Fernandez W, Borroto-Escuela D0, Vargas-Barroso V, Narváez M, Di Palma M, Agnati LF, et al. Dopamine D1 and D2 receptor immunoreactivities in the arcuate-median eminence complex and their link to the tubero-infundibular dopamine neurons. Eur J Histochem 2014;58:2400. 
79. Escobar ML, Echeverría OM, García G, Ortíz R, Vázquez-Nin GH. Immunohistochemical and ultrastructural study of the lamellae of oocytes in atretic follicles in relation to different processes of cell death. Eur J Histochem 2015;59:2535.

80. Mangas A, Yajeya J, González N, Duleu S, Geffard M, Coveñas R. NO-tryptophan: a new small molecule located in the rat brain. Eur J Histochem 2016;60:2692.

81. Merigo F, Boschi F, Lasconi C, Benati D, Sbarbati A. Molecules implicated in glucose homeostasis are differentially expressed in the trachea of lean and obese Zucker rats. Eur J Histochem 2016;60:2557.

82. Ayarza E, González M, López F, FernándezDonoso R, Page J, Berrios S. Alterations in chromosomal synapses and DNA repair in apoptotic spermatocytes of Mus $\mathrm{m}$. domesticus. Eur J Histochem 2016;60: 2677.

83. Strobel S, Encarnação JA, Becker NI, Trenczek TE. Histological and histochemical analysis of the gastrointestinal tract of the common pipistrelle bat (Pipistrellus pipistrellus). Eur J Histochem 2015;59:2477.

84. Di Giancamillo A, Andreis ME, Taini P, Veronesi MC, Di Giancamillo M, Modina SC. Cartilage canals in newborn dogs: histochemical and immunohistochemical findings. Eur J Histochem 2016;60:2701.

85. Cutroneo G, Centofanti A, Speciale F, Rizzo G, Favaloro A, Santoro G, et al. Sarcoglycan complex in masseter and sternocleidomastoid muscles of baboons: an immunohistochemical study. Eur J Histochem 2015;59:2509.

86. Torres-da-Silva KR, Da Silva AV, Barioni NO, Tessarin GW, De Oliveira JA, Ervolino E, et al. Neurochemistry study of spinal cord in non-human primate (Sapajus spp.). Eur J Histochem 2016;60:2623.

87. Fede C, Albertin G, Petrelli L, Sfriso MM, Biz C, De Caro R, et al. Expression of the endocannabinoid receptors in human fascial tissue. Eur J Histochem 2016;60: 2643.

88. Fede C, Albertin G, Petrelli L, Sfriso MM, Biz C, De Caro R, et al. Hormone receptor expression in human fascial tissue. Eur $\mathrm{J}$ Histochem 2016;60:2710.

89. Caprara G A, Perni S, Morabito C, Mariggiò MA, Guarnieri S. Specific association of growth-associated protein 43 with calcium release units in skeletal muscles of lower vertebrates. Eur J Histochem 2014;58:2453.

90. Liu Y, Weng J, Huang S, Shen Y, Sheng $X$, Han $Y$, et al. Immunoreactivities of PPARgamma2 leptin and leptin receptor in oviduct of Chinese brown frog during breeding period and pre-hibernation. Eur J Histochem 2014;58:2422.

91. Akat E, Arikan H, Gocmen B. Histochemical and biometric study of the gastrointestinal system of Hyla orientalis (Bedriaga 1890) (Anura Hylidae). Eur J Histochem 2014;58:2452.

92. Seliverstova EV, Prutskova NP. Receptormediated endocytosis of lysozyme in renal proximal tubules of the frog Rana temporaria. Eur J Histochem 2015;59: 2482.

93. Zhang H, Guo X, Zhong S, Ge T, Peng S, $\mathrm{Yu}$, et al. Heterogeneous vesicles in mucous epithelial cells of posterior esophagus of Chinese giant salamander (Andrias davidianus) . Eur J Histochem 2015;59:2521.

94. Úbeda-Manzanaro M, Ortiz-Delgado JB, Sarasquete C. The Bromodomain testisspecific gene (Brdt) characterization and expression in gilthead seabream, Sparus aurata, and European seabass, Dicentrarchus labrax. Eur J Histochem 2016;60:2638.

95. Zhang H, Yu P, Zhong S, Ge T, Peng S, Zhou Z, et al. Gliocyte and synapse analyses in cerebral ganglia of the Chinese mitten crab, Eriocheir sinensis: ultrastructural study. Eur J Histochem 2016;60:2655.

96. Marzo S, Galimberti V, Biggiogera M. Unexpected distribution of KRIT1 inside the nucleus: new insight in a complex molecular pathway. Eur J Histochem 2014;58:2358.

97. Aredia F, Malatesta M, Veneroni P, Bottone MG. Analysis of ERK3 intracellular localization: dynamic distribution during mitosis and apoptosis. Eur J Histochem 2015;59:2571.

98. Ayarza E, González M, López F, FernándezDonoso R, Page J, Berrios S. Alterations in chromosomal synapses and DNA repair in apoptotic spermatocytes of Mus $\mathrm{m}$. domesticus. Eur J Histochem 2016;60: 2677.

99. Ami D, Di Segni M, Forcella M, Meraviglia V, Baccarin M, Doglia SM, et al. Role of water in chromosome spreading and swelling induced by acetic acid treatment: a FTIR spectroscopy study. Eur J Histochem 2014;58:2330.

100. Korzhevskii DE, Sukhorukova EG, Kirik OV, Grigorev IP. Immunohistochemical demonstration of specific antigens in the human brain fixed in zinc-ethanol-formaldehyde. Eur J Histochem 2015;59: 2530.

101. Rieger J, Janczyk P, Hünigen H, Plendl J. Enhancement of immunohistochemical detection of Salmonella in tissues of experimentally infected pigs. Eur J Histochem 2015;59:2516.

102. Pinto AJ, de Amorim IF, Pinheiro LJ,
Madeira IM, Souza CC, Chiarini-Garcia H, et al. Glycol methacrylate embedding for the histochemical study of the gastrointestinal tract of dogs naturally infected with Leishmania infantum. Eur J Histochem 2015;59:2546.

103. Percival KR, Radi ZA. A modified Verhoeff's elastin histochemical stain to enable pulmonary arterial hypertension model characterization. Eur J Histochem 2016;60:2588.

104. Dall'Oca C, Maluta T, Cavani F, Morbioli GP, Bernardi P, Sbarbati A, et al. The biocompatibility of porous vs non-porous bone cements: a new methodological approach. Eur J Histochem 2014;58:2255.

105. Perdoni F, Falleni M, Tosi D, Cirasola D, Romagnoli S, Braidotti P, et al. A histological procedure to study fungal infection in the wax moth Galleria mellonella. Eur J Histochem 2014;58:2428.

106. Fede C, Fortunati I, Petrelli L, Guidolin D, De Caro R, Ferrante C, et al. An easyto-handle microfluidic device suitable for immunohistochemical procedures in mammalian cells grown under flow conditions. Eur J Histochem 2014;58:2360.

107. Kammoun M, Cassar-Malek I, Meunier B, Picard B. A simplified immunohistochemical classification of skeletal muscle fibres in mouse. Eur $\mathrm{J}$ Histochem 2014;58:2254

108. Schläfli AM, Berezowska S, Adams 0, Langer R, Tschan MP. Reliable LC3 and p62 autophagy marker detection in formalin fixed paraffin embedded human tissue by immunohistochemistry. Eur J Histochem 2015;59:2481.

109. Paulsen IM, Dimke H, Frische S. A single simple procedure for dewaxing, hydration and heat-induced epitope retrieval (HIER) for immunohistochemistry in formalin fixed paraffin-embedded tissue. Eur J Histochem 2015;59:2532.

110. Chen W, Liang J, Huang L, Cai J, Lei Y, Lai $\mathrm{J}$, et al. Characterizing the activation of the Wnt signaling pathway in hilar cholangiocarcinoma using a tissue microarray approach. Eur J Histochem 2016;60:2536

111. Šoštarić-Zuckermann IC, Severin K, Huzak M, Hohšteter M, Gudan Kurilj A, Artuković B, et al. Quantification of morphology of canine circumanal gland tumors: a fractal based study. Eur J Histochem 2016;60:2609.

112. Cabibi D, Giannone A G, Mascarella C, Guarnotta C, Castiglia M, Pantuso G, et al. Immunohistochemical/histochemical double staining method in the study of the columnar metaplasia of the oesophagus. Eur J Histochem 2014;58:2326.

113. Emde B, Heinen A, Godecke A, 
Bottermann K. Wheat germ agglutinin staining as a suitable method for detection and quantification of fibrosis in cardiac tissue after myocardial infarction. Eur J Histochem 2014;58:2448.

114. Bonetti A, Bonifacio A, Della Mora A, Livi U, Marchini M, Ortolani F. Carotenoids co-localize with hydroxyapatite, cholesterol, and other lipids in calcified stenotic aortic valves. Ex vivo Raman maps compared to histological patterns. Eur J Histochem 2015;59:2505.

115. Accart N, Dawson J, Kolbinger F, Kramer I, Beckmann N. Histological validation of non-invasive imaging in an ankylosing spondylitis rat adjuvant model. Eur $\mathbf{J}$ Histochem 2016;60:2667.

116. Busato A, Fumene Feruglio P, Parnigotto PP, Marzola P, Sbarbati A. In vivo imaging techniques: a new era for histochemical analysis. Eur J Histochem 2016;60:2725.

117. Croce AC, Bottiroli G. Autofluorescence spectroscopy and imaging: a tool for biomedical research and diagnosis. Eur J Histochem 2014;58:2461.

118. Croce AC, Bottiroli G. New light in flavin autofluorescence. Eur J Histochem 2015;59:2576.

119. Di Guardo G. Lipofuscin, lipofuscin-like pigments and autofluorescence. Eur J Histochem 2015;59:2485.

120. Sainz B Jr, Miranda-Lorenzo I, Heeschen C. The fuss over lipo"fuss"cin: not all autofluorescence is the same. Eur $J$
Histochem 2015;59:2512.

121. Salucci S, Burattini S, Falcieri E, Gobbi P. Three-dimensional apoptotic nuclear behavior analyzed by means of Field Emission in Lens Scanning Electron Microscope. Eur J Histochem 2015;59: 2539 .

122. Scimeca M, Orlandi A, Terrenato I, S Bischetti, Bonanno E. Assessment of metal contaminants in non-small cell lung cancer by EDX microanalysis. Eur J Histochem 2014;58:2403.

123. Frontalini F, Curzi D, Giordano FM, Bernhard JM, Falcieri E, Coccioni R. Effects of lead pollution on Ammonia parkinsoniana (foraminifera): ultrastructural and microanalytical approaches. Eur J Histochem 2015;59:2460.

124. Scimeca M, Pietroiusti A, Milano F, Anemona L, Orlandi A, Marsella LT, et al. Elemental analysis of histological specimens: a method to unmask nano asbestos fibers. Eur J Histochem 2016;60:2573.

125. Poletto V, Galimberti V, Guerra G, Rosti V, Moccia F, Biggiogera M. Fine structural detection of calcium ions by photoconversion. Eur J Histochem 2016;60:2695.

126. Grecchi S, Malatesta M. Visualizing endocytotic pathways at transmission electron microscopy via diaminobenzidine photo-oxidation by a fluorescent cellmembrane dye. Eur J Histochem 2014;58:2449.

127. Costanzo M, Carton F, Marengo A, Berlier
G, Stella B, Arpicco S, et al. Fluorescence and electron microscopy to visualize the intracellular fate of nanoparticles for drug delivery. Eur J Histochem 2016;60:2640.

128. Malatesta M, Grecchi S, Chiesa E, Cisterna B, Costanzo M, Zancanaro C. Internalized chitosan nanoparticles persist for long time in cultured cells. Eur J Histochem 2015;59:2492.

129. Malatesta M. Transmission electron microscopy for nanomedicine: novel applications for long-established techniques. Eur J Histochem 2016;60:2751.

130. Pellicciari C, Biggiogera M. (Eds) Histochemistry of single molecules Methods and Protocols. Humana Press; 2017.

131. Taatjes DJ, Roth J. The histochemistry and cell biology pandect: the year 2014 in review. Histochem Cell Biol 2015;143:339-68.

132. Klein T, Proppert S, Sauer M. Eight years of single-molecule localization microscopy. Histochem Cell Biol 2014; 141:561-75

133. Schermelleh L, Heintzmann R, Leonhardt $\mathrm{H}$. A guide to super-resolution fluorescence microscopy. J Cell Biol 2010;190: 165-75.

134. Ilgen P, Stoldt S, Conradi LC, Wurm CA, Rüschoff J, Ghadimi BM, et al. STED super-resolution microscopy of clinical paraffin-embedded human rectal cancer tissue. PLoS One 2014;9:e101563. 